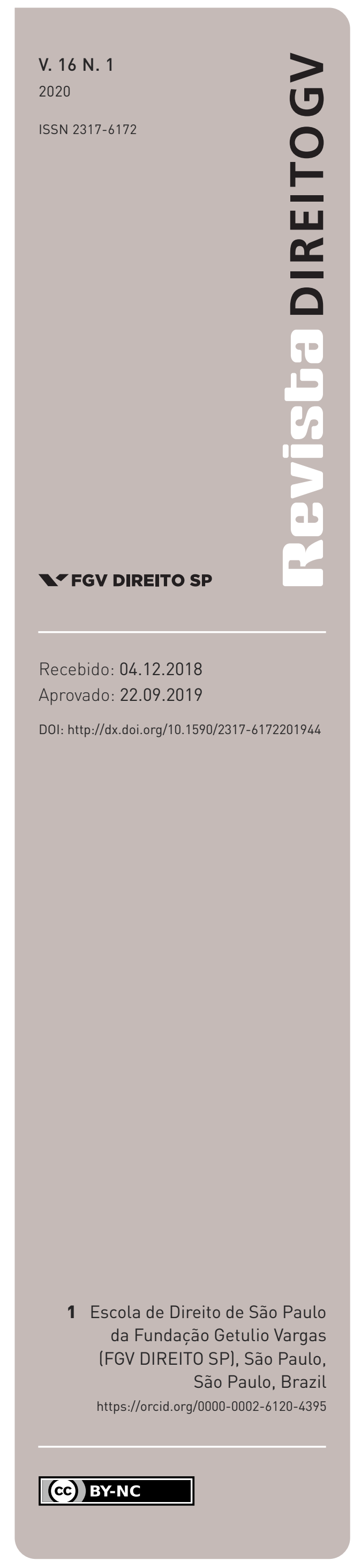

\title{
A feminist analysis of child neglect cases from the Brazilian Superior Court of Justice
}

UMA ANÁLISE FEMINISTA DO ABANDONO AFETIVO NO SUPERIOR TRIBUNAL DE JUSTIÇA

Flavia Portella Püsche1 ${ }^{1}$

\begin{abstract}
This article analyzes the opinions of judges of the Brazilian Superior Court of Justice (STJ) in child neglect cases from a feminist perspective by "asking the woman question" to identify implicit male bias in legal concepts and standards that are apparently gender neutral. Several sexist arguments can be found both in opinions against awarding damages for child neglect and in opinions in favor of it. Sexist bias is shown in the disregard of legal doctrine, as well as of the ambivalent character of family relations and their hierarchical structure. This bias is further expressed in the devaluation of women's interests and life experiences, stereotyping, problems of logical reasoning as well as in the disregard of statutory rules. The article concludes that the STJ was unable to take into account the point of view of women and the circumstances in which child neglect actually takes place in Brazilian society today. The court developed a concept of harm that, although apparently gender neutral, is based on discriminatory reasons and has greater negative impact on women than on men.
\end{abstract}

\section{Keywords}

Feminist legal theory; gender bias; child neglect; tort law; precedents of the Brazilian Superior Court of Justice (STJ).

\section{Resumo}

Neste artigo, as posições defendidas pelos ministros do Superior Tribunal de Justiça (STJ) acerca da responsabilidade civil por abandono afetivo são analisadas de uma perspectiva feminista, com emprego de método pelo qual se tornam explícitos vieses machistas implícitos em conceitos e standards jurídicos aparentemente neutros. Encontram-se nas decisões analisadas diversos argumentos discriminatórios, tanto em votos desfavoráveis quanto em votos favoráveis à reparação por abandono afetivo. Os vieses machistas se mostram pela desconsideração da tradição jurídicodogmática e da doutrina especializada, bem como pela desconsideração do caráter ambivalente das relações familiares e suas estruturas hierárquicas, passando pela desvalorização expressa de interesses e experiências de vida femininas, pelo uso de estereótipos femininos negativos e por problemas de lógica argumentativa e interpretação sistemática do Direito, chegando até a desconsideração de norma legal expressa. Conclui-se que o STJ não foi capaz de levar em conta o ponto de vista feminino e as circunstâncias concretas em que o abandono afetivo acontece hoje no Brasil, tendo desenvolvido o conceito jurídico de dano indenizável em um sentido que, apesar de aparentemente neutro, é fundado em razões discriminatórias e atinge as mulheres de modo desproporcionalmente negativo em comparação com os homens.

\section{Palavras-chave}

Análise feminista do direito; viés de gênero; abandono afetivo; responsabilidade civil; jurisprudência do Superior Tribunal de Justiça (STJ). 


\section{INTRODUCTION*}

In 2005 the Brazilian Superior Court of Justice (STJ) ruled its first case of tort liability for nonpecuniary damages arising from child neglect (BRAZIL, 2005). Child neglect in this context means the absence of the parent and the lack of psychological and moral support on the parent's part during the child's development. Liability for non-pecuniary damages for child neglect is distinguished from liability for lack of material support and can, therefore, be attributed even to parents who have regularly contributed financially to the support of their offspring.

This is a subject that has aroused great controversy in Brazil, both among legal scholars ${ }^{1}$ and in the courts. In the STJ itself, as of 2005, different positions were formed, which culminated in a trial to uniformize the positions of the court's Panels on the issue in 2014.

In this article, we will analyze the different positions defended by the STJ justices, from a feminist perspective of law, that is, by applying a method of analysis of law that reflects:

the status of women as "outsiders," who need ways of challenging and undermining dominant legal conventions and of developing alternative conventions that take better account of women's experiences and needs. (BARTLETT, 1990, p. 831)

The purpose of feminist theories of law, such as the one we use here, is to contribute to harness the power of law in building gender equality rather than to perpetuate patriarchal patterns of subordination (CHAMALLAS, 2003, p. 22). ${ }^{2}$

Among the different methods employed in feminist legal research, this work applies one associated with the line of investigation - still little explored in the reflections on private law in Brazil - that seeks to make explicit the male biases implicit in apparently neutral concepts and standards ${ }^{3}$ (CHAMALLAS, 2003, p. 6).

In this context, bias indicates not only practices intentionally aimed at harming women, but also those whose impacts or negative effects on women are unintended (CHAMALLAS, 2003, p. 7).

* Traslator: Elizabeth Ann Miller.

1 The academic debate is not the object of this work, so we will not deal with the positions found in the literature. For an overview of the discussions, see, among others: Hironaka (2006, p. 131-149), Madaleno (2006, p. 151 169), Moraes (2006, p. 171-201), Pereira (2015, p. 399-410), and Schreiber (2015, p. 32-49).

2 In this sense, a work of critical analysis, such as feminist analysis of law, participates in the broader project of "reflecting on the effects of doctrine and court rulings on the distribution of power and social resources" (emphasis in original, our translation), identifying room for arbitrariness and proposing institutional reforms (RODRIGUEZ, 2012a, p. 12-13).

3 This is the method often referred to by the expression "asking the woman question" in English language literature (CHAMALLAS, 2003, p. 7; BARTLETT, 1990, p. 837-849). 
Such unintentional practices include discriminatory treatment due to insensitivity, lack of empathy, use of stereotypes or hostility to women. Practices that have a disproportionate negative effect on women as a group without legitimate justification are also included. Finally, the notion of bias also includes the devaluation of interests, activities, harm, etc., socially associated with women (CHAMALLAS; WRIGGINS, 2010, p. 24).

As one can see, in this analysis we are not aligned with any specific school of feminist thinking. We follow Martha Chamallas' proposal to adopt, from various feminist perspectives, a series of criteria for identifying situations of gender-based injustice (CHAMALLAS, 2013, p. 27).

Among these criteria are unjustified differential treatment, the contribution to an increase or maintenance of power differences between men and women in society, and the devaluation of activities socially associated with women (CHAMALLAS, 2013, p. 28-29).

Therefore, to identify implicit male biases one cannot limit the analysis to only formal equality. It is necessary to examine the real effects that law has on women as a group (CHAMALLAS, 2003, p. 6).

In this process, it must be borne in mind that even uncontroversial legal concepts can be detrimental to women, since the structuring of legal institutes reflects the viewpoint of those in power and thus tends to be invisible (CHAMALLAS, 2003, p. 7-8).

This is explained to the extent that law presupposes an idea of a gender neutral person, but in a context in which norms are in fact created by men, from the male point of view, based on the experiences of men's lives, without regard, therefore, to women's experiences from the point of view of women themselves (MacKINNON, 1989, p. 88). As Catharine MacKinnon $(1989$, p. 88) states, gender is invisible in law because it is not a relevant factor in distinguishing between men. As stated by Martha Chamallas (2003, p. 7-8):

Male-centered standards derive their force from being uncritically accepted as universal in nature. Challenging them is particularly difficult once they have gained legitimacy as an "objective” way of categorizing people and organizing people's activities and work.

We consider that the feminist analysis of law can be seen as manifesting a critical understanding of legal rationality, according to which "the role of [legal] doctrine in justifying court decisions under the Rule of Law [...], namely, its function is to translate into law the political principle of equality before the law [...]” (RODRIGUEZ, 2012a, p. 9, our translation).

In this sense, legal doctrine is an instrument not only of decision (and guarantee of legal certainty), but of the legitimation of decisions, which operates through a continuous process of systematization and re-systematization of law, based on the previous tradition, to account for new social conflicts (RODRIGUEZ, 2012b, p. 22-24).

Such a doctrinal process of development consists primarily of a social dispute practice to determine the meaning of legal norms, which takes place both within and outside the jurisdictional institutions through specialized doctrinal debate and the public sphere in general 
(RODRIGUEZ, 2012a, pp. 10-11). ${ }^{4}$

Given this, it is clear that any gender bias enters tort law - and other legal institutions - through the very process of its conceptual development (CHAMALLAS, 2013, p. 205).

We will test this hypothesis in the case of the development of liability for child neglect in the STJ. This is an interesting case for three reasons. The first of these is that there is clearly a gender division when it comes to parents who abandon their children: in the vast majority of cases, the father leaves the child in the mother's care. Data released by the Gender and Race Inequality Portrait (IPEA, n.d.) based on IBGE's National Household Survey (PNAD) showed a large difference between the number of households with single mothers and single fathers. In 2015, families composed of women with children represented $16.3 \%$ of the total Brazilian families, while families composed of men and children represented only $2.2 \%$. Although it is not possible to state from this data that the reason for the father's absence is always abandonment (and not widowhood, for example), it can be concluded that whatever the reason for the father's absence it is more common for women than men to be taking care of their children without the presence of the other parent. Another indication of the size of paternal abandonment in Brazil is the number of children without their father's name on their birth registration. Based on the 2011 school census conducted by National Institute for Educational Studies and Research “Anísio Teixeira” (INEP), the National Council of Justice (CNJ) estimated that there are more than 5 million students in this situation (CNJ, 2015, p. 10).

The second reason is that there is no express statutory norm about liability for child neglect, so the rules for its recognition as indemnifiable harm were created judicially, that is, already through doctrinal debate. This gives us a privileged perspective on how cognitive biases determine the development of legal concepts (in this case, the concept of indemnifiable harm).

Finally, rules of tort law are apparently neutral, that is, they do not expressly take into account the gender of any of the parties involved, a case in which male biases tend to become invisible.

In cases of child neglect, the invisibility of gender discrimination also occurs because actions in tort involve fathers and their daughters or sons, so that often both plaintiff and defendant are men. In order to see the gender issue involved in the conflict, it must be borne in mind that the relationship between plaintiff and defendant in this type of law suit arises in the context of family relations ${ }^{\mathbf{5}}$ in which the woman-mother also participates. ${ }^{6}$

4 Advancing to a more abstract level of analysis, this view of legal doctrine relates to the argumentative character of law, as advocated by Ronald Dworkin (1986) and Neil MacCormick (2005).

5 These are families formed from heteroaffective couples. The precedents of the STJ do not include cases of child neglect in families formed from homosexual couples, and we have no data on the occurrence of child neglect according to the sexual orientation of parents.

6 The focus on the family is relatively recent in the history of feminist legal theory, having gained relevance only since the 1990s, with the third generation of feminist legal theory (CHAMALLAS, 2013, p. 364). 
The hetero-affective family in Brazil is still strongly marked by gender-based roles, and women are primarily responsible for caring for children, the elderly and the sick, as well as performing housework. In addition, the percentage of women who perform paid work is still lower than men, with a pay gap in favor of men. Finally, it should not be forgotten that most families where women raise children alone live below the poverty line. ${ }^{\mathbf{7}}$

In her recent work on changes in Brazilian families, which analyzes the period from 1976 to 2012, Nathalie Reis Itaboraí points out that data reveals "a tendency for continuous change, which occurs in all [social] classes, towards a better relative position for women in relation to their partners" (ITABORAÍ, 2017, p. 214, our translation). Still, the asymmetry of power between men and women persists. According to the same author, certain dimensions of gender stratification, especially cultural expectations about the feminine character of domestic and care duties, are very resistant to change and act as a limit to the processes of female emancipation (ITABORAÍ, 2017, p. 342). ${ }^{\mathbf{2}}$

It is evident, therefore, that the burden of domestic work and childcare has a major impact on women's economic situation and, consequently, on their possibilities of achieving the constitutionally prescribed gender equality. The situation is especially serious in the case of women who take care of their children alone, as is the case of families involved in tort liability actions for child neglect.

Martha Albertson Feinman points out that feminists themselves devalued the family as an object of study (FEINMAN, 1993, p. 403, n. 33).

7 According to IBGE's 2017 National Continuous Household Survey 2017 (PNAD Contínua), in that year the number of weekly hours that women devoted to housework was approximately twice that of men (RENAUX, 2018a). Regarding the pay gap, according to PNAD Contínua data for the fourth quarter of 2018, women earn on average $20.5 \%$ less than men. In addition to earning less per hour worked, women work fewer hours, which is related to the time they spend on household chores and caring for people (PARADELLA, 2019). According to the IBGE Social Indicators Synthesis, released in 2018, 56.9\% of the residents of households with single women with children under 14 live below the poverty line, with an income of up to $\mathrm{R} \$ 406$ monthly. In comparison, residents of households with couples with children who live below the poverty line are $30.4 \%$ (RENAUX, 2018b).

8 Obstacles are especially severe for lower-income women, who, in addition to having fewer job opportunities, tend to have a higher domestic workload and fewer alternatives to outsource domestic tasks (ITABORAÍ, 2017, p. 342). In addition to social class, data from the IBGE Social Indicators Summary, released in 2018 , indicate that race is also an important component in defining the impact of domestic and care responsibilities. Thus, $64.4 \%$ of residents in households with single women and children under 14 live below the poverty line when the woman is black or brown. In comparison, the percentage of people living below the poverty line in households where white single women with children under 14 live is $41.5 \%$. As stated above, the overall percentage of people living below the poverty line in households with single women with children under 14 years of age is $56.9 \%$ and $30.4 \%$ in households with couples and children under 14 (RENAUX, 2018b). 
The relevant relationship for our analysis is not, therefore, simply that between the defendant, man-father, and his daughter or son, but above all, the relationship between man-father and woman-mother, constructed from family relationships, which has influence on the decision of the justices, regardless of whether the woman-mother enters the judicial process.

We will begin the analysis by describing the cases and court decisions, from the first time the matter arose, to the unified ruling of the STJ. Next, we will analyze the different positions defended by the Justices, considering their male bias, followed by the conclusions about the hypothesis raised.

Before that, however, some clarification needs to be made. Feminist legal theory has been criticized for defending norms that favor women simply because they favor women (SCHWARTZ, 2001, p. 201). This is not the purpose of this text, regardless of whether this criticism is appropriate or not. What interests us are the rules that treat women unfavorably without adequate justification, thus contradicting the constitutional principle of equality between women and men (FEDERAL CONSTITUTION [FC], art. 5, I) and the prohibition of discrimination (FC, art. 3, IV).

Secondly, it must be made clear from the outset that this paper makes no quantitative statement on the prevalence of gender bias in court rulings or in private law in general. ${ }^{9}$ Our objective is to demonstrate that the discrimination of women through the biased development of doctrinal concepts is an observable reality in Brazilian law.

\section{I.THE DECISIONS OFTHE STJ}

The first case of tort liability for child neglect tried by the STJ was REsp n. $757411^{10}$ (BRAZIL, 2005). This is a tort liability action brought by a son against his father, claiming compensation for non-pecuniary damages because, since the divorce of the parents and the birth of the father's daughter by his second wife, the father avoided contact with the son, thus failing to provide him with psychological and moral assistance, even though the father fulfilled his obligation to provide child support. The son claims not to have had the opportunity to meet and live with his half-sister, to have been ignored in his attempts at rapprochement and to

9 It must be said, however, that since law is created by men, from the male point of view based on male experiences, without taking into account female experiences from the female point of view (MacKINNON, 1989 , p. 88), the tendency is that the presence of gender bias is not punctual, but pervasive and systemic.

10 The REsp (Recurso Especial) is an appeal that may be presented to the STJ to fight a decision of a second instance tribunal that contradicts federal statutes or interprets such statutes in a different way than other second instance tribunals. It is a special appeal designed to guarantee the application of federal statutes and to uniformize their interpretation by state and federal tribunals (FC, art. 105, III). 
not have been able to count on his father's presence at important moments in his life, which caused him extreme suffering and humiliation (BRAZIL, 2005, p. 2).

The father, in turn, claims that the tort lawsuit is a retaliation on the part of his ex-wife, mother of the plaintiff, due to the fact that he asked for a reduction of child support payments. In addition, he claims that it was the ex-wife's attitude - insulting phone calls and instructions for her son to assault his half-sister - that caused the father's removal because "[these actions] made the domestic situation during the biweekly visitation unbearable" (BRAZIL, 2005 , p. 2, our translation).

In addition, the father claims to have traveled a lot, both in Brazil and abroad, which also compromised the regularity of his meetings with his son, and claims to offer encouragement to his son via telephone contact (BRAZIL, 2005, p. 2-3).

The action was dismissed as groundless by the first-instance judge. An appeal was filed with the Minas Gerais State High Court which upheld the appeal and ordered the father to pay non-pecuniary damages amounting to $\mathrm{R} \$ 44,000$. Given this, the father filed a Special Appeal with the STJ (BRAZIL, 2005, p. 3-4).

The 4th Panel of the STJ upheld the appeal, by a majority vote, denying damages, on November 29, 2005. Justice Barros Monteiro dissented (BRAZIL, 2005, p. 1).

The 4th Panel of the STJ judged another case of tort liability for child neglect in 2009. This was REsp n. 514350 (BRAZIL, 2009a). Between the first and second trials, there was a major change in the composition of the 4th Panel. Three justices had been replaced. Only Justice Aldir Passarinho Jr. participated in both trials and was rapporteur of the 2009 judgment. Despite the change in its composition, the 4th Panel retained its previous understanding, ${ }^{11}$ this time unanimously, on the same grounds as the 2005 decision (BRAZIL, 2009a, p. 10).

In 2012, there was the first ruling on the matter by the 3rd Panel of STJ, in the REsp n. 1159242 (BRAZIL, 2012). The case was a tort liability action brought by a daughter against her father seeking compensation for material and non-pecuniary damages resulting from both material and moral neglect during her childhood and youth. The action was dismissed as groundless by the first-instance judge. The daughter filed an appeal, which was upheld by the São Paulo Court of Justice, and the amount of R \$ 415,000 was established as compensation for non-pecuniary damages. The father then filed a Special Appeal with the STJ, alleging that he did not neglect his daughter and that, even if he had, this fact did not constitute a tort, and the only possible legal sanction was the loss of parental authority. He also referred to the previous ruling by the 4th Panel, regarding the impossibility of compensation for child neglect (BRAZIL, 2012, p. 3-4).

11 Only the rapporteur, Justice Aldir Passarinho Jr., wrote an opinion which was validated by the others. 
The 3rd Panel decided, by majority, to grant the appeal in part, recognizing the right to damages for child neglect, but reducing the value of the compensation to $\mathrm{R} \$ 200,000$. Justice Massami Uyeda, who granted the father's appeal, was defeated (BRAZIL, 2012, p. 14; 49).

Given the only partial provision of his Special Appeal, the father filed an Embargo de Divergência (which is an appeal to the STJ to uniformize its position regarding a question of law when there are conflicting rulings among its panels), based on the difference of understanding on the possibility of recovery for child neglect in the 3rd and 4th Panels of STJ (BRAZIL, 2014, p. 4).

In 2014, the Second Chamber of the STJ decided, by a majority vote, to dismiss the Embargos de Divergência without judging the merits of the case (BRAZIL, 2014, p. 8-40). The understanding that the ruling by the 3rd Panel represented only an exception to the rule of irreparability defined by the 4th Panel, so that there was not really any disagreement between the panels, prevailed.

In short, the result of the discussions in the STJ was the establishment of the irreparability of moral damages for child neglect as a rule with the possibility of reparation as an exception. ${ }^{12}$

\section{MALE BIAS IN THE ARGUMENT}

Several of the arguments presented in the decisions of the first four cases of tort liability for child neglect in the STJ have a sexist bias, even in votes in favor of redress for this type of damage.

Let us organize the analysis by the content of the argument, indicating the judgments in which they appear.

\section{I REPARATION IS UNNECESSARY}

The first reason given for denying reparation for non-pecuniary damages for child neglect is that it is unnecessary, since all the purposes that could justify non-pecuniary damages would already be fulfilled by other legal means (BRAZIL, 2005, p. 9). These functions would be: punishment, deterrence, and reparation (BRAZIL, 2005, p. 7-9).

Regarding punishment and deterrence, says Justice Fernando Gonçalves (BRAZIL, 2005, p. 7-8, emphasis in original, our translation):

12 However, this solution raises many problems. According to Püschel and Aquino (2019, p. 198, our translation), "the arguments brought by the 3rd Panel to admit civil liability for child neglect in certain circumstances do not establish an exception to the rule defended by the 4th Panel, but refer to a different rule. To consider the decision of the 3rd Panel as an exception to the rule previously established by the 4th Panel would be to admit a logical contradiction”. In addition, by failing to judge the merits of the Embargos de Divergência, the Second Chamber of the STJ failed to establish the requirements for recognition of the proclaimed exception (PÜSCHEL; AQUINO, 2019, p. 201). 
In case of abandonment or unjustified non-compliance with the duty of child support, custody and education of children [...] the legislation provides as punishment the loss of parental authority [...] both in the Statute of the Child and Adolescent, art. 24, as in the Civil Code, art. 1638, item II. Thus, the legal system, with the determination of the loss of parental authority, the most serious civil penalty to be imposed on a father, already takes care of the punitive function and acts as a deterrent, showing effectively to individuals that the Law and society do not sympathize with the conduct of abandonment, with which the most poignant justification of those who defend indemnity for child neglect falls to the ground.

Regarding the objective of material reparation, this would not justify liability, since such purpose is fulfilled by the payment of child support (BRAZIL, 2005, p. 9).

With this argument, there is a complete reversal of the sanction of loss of parental authority, which is fundamentally a means of protecting the minor and not a punishment for the wrongful father (DIAS, 2011, p. 434; LOBO, 2018, p. 309).

How could the loss of parental authority be considered a punishment for non-compliance with parental duties, if such a sanction establishes precisely the loss of such duties? We would have a conduct punished with its equivalent: the removal of the father would be punished with the removal of the father, which makes no sense, even logically. ${ }^{13}$

Moreover, it is difficult to imagine that the confirmation as legitimate of what a subject already wanted (withdrawal from the child) can have a deterrent effect. Deterrence depends on whether people fear the imposition of the sanction and therefore cease to commit the unlawful act (PÜSCHEL, 2011, p. 169). Of course, it is not possible to believe that a father who intends to abandon his son is afraid of the sanction of loss of parental authority. This is "the most serious civil penalty to be imputed to a father" (BRAZIL, 2005, p. 8, our translation) only when the father does not want to give up his duties towards his son.

Finally, in regards to the material reparation, child support is not reparative. It derives from parenthood and not from the practice of an unlawful act (DIAS, 2011, p. 513).

In this case the argument can be considered sexist in that, by refusing legal sanction to the offending father, it protects men who leave their offspring, reinforcing the difference of power between men and women already observed in society, by overloading the woman-mother with the care of the children. In addition, it minimizes the importance of caring for the offspring, devaluing a socially considered female activity. 


\subsection{EXCLUSIVE APPLICATION OF FAMILY LAW}

Related to the previous argument, there is the notion that the rules of tort liability do not apply to family relations, defended by Justice Aldir Passarinho Junior and Justice Cesar Asfor Rocha. The latter justifies it, stating that "Family Law has its own principles that cannot be influenced by other principles that are exclusively related or - at least - more strongly related to other branches of law" (BRAZIL, 2005, p. 14, our translation).

An attenuated version of this same argument is defended by Justice Paulo de Tarso Sanseverino, in an opinion in which he defends non-pecuniary damages in family matters, but only in very exceptional and extreme cases of "effective excess in family relations" (BRAZIL, 2012, p. 41, our translation). The rationale for this would be that:

Due to the very delicate nature of family relationships, tort liability in Family Law cannot be equated with tort liability in general, otherwise it would require a degree of caution in daily family life that is incompatible with family relationships, besides it would lead to an undesirable patrimonialization of personal relationships, precisely in their most intimate aspect. (BRAZIL, 2012, p. 41, our translation)

However, the family can be a protective environment for some and of suffering for others. To exclude family relationships from sanctions for the practice of unlawful acts is thus to preserve the differences of power existing in family relations, harming their most vulnerable members.

The data on domestic violence shows the hierarchy in family relations and leaves no doubt that the exclusion of sanctions for unlawful acts within the family has different effects according to gender, harming especially women. The 2015 Map of Violence: Homicide of Women (Mapa da violência 2015: Homicídio de mulheres no Brasil), for example, indicates that women are more likely to experience violence in their own homes, while men suffer more violence on the street, and assaults on women are more often committed by people known to the victim, while men are more often attacked by strangers (WAISELFISZ, 2015, p. 74). ${ }^{14}$

Home and family are not an environment of equality between men and women, so excluding civil liability sanctions from family relations has the effect of disadvantaging women and contributing to the perpetuation of inequality.

14 In the same vein, the 2011 United Nations Office on Drugs and Crimes (UNODC) global study concluded that this is a well-documented situation and is not restricted to Brazil (UNODC, 2011, p. 58). 


\subsection{THE REPARATION MEETS THE INTERESTS OFTHE FORMER PARTNER}

According to this argument, attributing liability to the parent who has abandoned his child could serve as a way of satisfying the interests of the other parent, both personal and economic. According to Justice Fernando Gonçalves:

It should be borne in mind that often the one with sole child custody transfers to the child feelings of hatred and revenge nurtured against their former partner, not to mention that compensation may not exactly ease the suffering of the minor, but also satisfy the financial ambition of the person rejected in the romantic relationship. (BRAZIL, 2005, p. 8, our translation)

Despite the seemingly neutral language, it is possible to see the effect of gender stereotypes on this argument. The justice refers to the fact that it is common for the parent "with sole child custody" to transfer feelings of hatred and revenge against the former partner and seek to satisfy their own financial ambitions at the expense of their former partner.

The justice does not consider the possibility that feelings of hatred and revenge, as well as financial ambitions, may be reciprocal, or held by the parent who abandons the child.

Considering that, as stated above, it is usually the fathers who abandon and the mothers who keep custody, it is clear that the justice refers to women-mothers as transfering feelings of hatred and revenge to their children, in addition to having the disreputable purpose of enriching themselves at the expense of the man-father.

Given the familiar subterfuges employed by many men-fathers to lower child support or exclude the unwanted child from inheritance, ${ }^{15}$ it seems reasonable to suppose that feelings of hatred and revenge, as well as greed, tend to be at least, as frequent among the parents who abandon their children, as among those who are left with sole custody of the child. So the argument makes an arbitrary distinction between the parents who abandon their children and those who stay with their children, leaving the latter disadvantaged - those who as already said - are mostly women-mothers.

As for the supposed goal of getting rich at the expense of ex-partners, as we mentioned above, poverty data in households where a woman and children under 14 live indicate that divorce tends to have a disproportionately negative financial impact on women-mothers compared to men-fathers. This situation is reinforced by the argument under consideration, formulated without reference to any specific aspect of the cases on trial or consideration of the population data, thus based solely on the judges' prejudices. 


\subsection{THE POSSIBILITY TO RECONSTRUCT THE RELATIONSHIP MUST BE PRESERVED}

According to this argument, holding the father liable for child neglect should be avoided, since it would compromise the possibility of reconciliation between father and child. In the words of Justice Fernando Gonçalves:

Perhaps by admitting indemnity for child neglect we are definitively burying the possibility of a father, either now or in old age, seeking protection in the love of his children [...] Certainly a dispute between the parties would drastically reduce hope of the child being welcomed, albeit belatedly, by paternal love. (BRAZIL, 2005, p. 9, our translation)

The protection of the family and the conciliatory objective linked to this idea are arguments found in other situations of discrimination against women. ${ }^{16}$ Again, it must be borne in mind that the preservation of the family in this context means the preservation of the gender hierarchy in family relations. Interestingly in the case of Justice Fernando Gonçalves the protection seems to be directly aimed at the interest of the father, who may want to seek the protection of his child.

A variant of this argument appears in the opinion of Justice Massami Uyeda, for whom the recognition of liability for child neglect by the court would bring an end to peace, establishing a "strife within the family" (BRAZIL, 2012, p. 16).

\subsection{IMPOSSIBILITY OF FORCING SOMEONETO LOVE}

According to the argument defended by Justice Fernando Gonçalves, there can be no liability for child neglect because the law cannot compel someone to love (BRAZIL, 2005, p. 10).

By qualifying the issue in terms of the lack of a legal duty to love, this argument reduces the duties of paternity to the material needs of the child, contrary to the express legal provision

tance rights (BRAZIL, 2012, p. 37-38). This matter was tried by the Court of Appeal of the State of São Paulo (TJSP) (BRAZIL, 2009b), which confirmed the first-instance sentence of nullity of the fraudulent contract celebrated to the detriment of the unwanted daughter.

16 As an example we can mention the practice identified in the treatment of violence against women cases in the Special Criminal Courts (Jecrim), where "The judge's perception of what the family is and the importance of its social role" was what guided decisions, with the "expected performance of roles by men and women in the family script" replacing "women as subjects of rights", a situation that is much criticized by feminist movements (DEBERT; BERALDO DE OLIVEIRA, 2007, p. 331-332, our translation). According to Marcella Beraldo de Oliveira, at Jecrim the focus was "on achieving quick conciliation, preserving the family and its hierarchies, reifying the relationship of violence” (2008, p. 46). 
(art. 1,634, I, of the Civil Code [CC]) and to the dominant doctrinal understanding (DIAS, 2011, p. 425; LOBO, 2018, p. 313). ${ }^{17}$

An argument that is related to the idea of impossibility of forcing someone to love is the rejection of transforming affection into money, which is found in the opinion of Justice Cesar Asfor Rocha (BRAZIL, 2005, p. 14).

It should be noted, however, that such an objection could be made toward liability for nonpecuniary damages generally, since it results from injury to personal rights and - by definition - has no monetary value. ${ }^{18}$ This general issue of non-pecuniary damages was resolved by the constitutional provision (art. 5, V and X, FC) and legal provision (art. 186, CC) that expressly recognize the reparability of non-pecuniary damages, so that the justice should have substantiated the differential treatment that he gave in this case. Without such substantiation, we are left with an unjustified differentiation, which in practice favors men.

\subsection{CHILD NEGLECT AS A FACT OF LIFE}

There is also the argument presented by Justice Massami Uyeda, in the sense that child neglect and its consequences are facts of life (BRAZIL, 2012, p. 16) and, as such, not indemnifiable.

According to the justice, any child may feel deprived compared to their siblings, a situation that could also occur between spouses and in family relationships in general, since no one is perfect (BRAZIL, 2012, p. 16). Life, says the justice, "is made up of losses and gains, perhaps even more losses than gains" and - with the expressiveness of oral manifestations - he concludes: "If we open this thesis here, as people would say, run for the hills. This Court will take care of heartbreak" (BRAZIL, 2012, p. 25, our translation).

Here we have the explicit devaluation of the damages suffered in family relationships. Given the power asymmetry within the family, this amounts to privileging its strongest members over the most vulnerable. The privileged position of the man-father in relation not only to their daughters and sons, but also to the woman-mother is reinforced.

A mitigated version of this argument is defended by Justice Paulo de Tarso Sanseverino, who is in favor of reparation for child neglect only in exceptional situations. According to the justice, frustrations that occur in the family contribute to the growth of the individual, ${ }^{19}$ and are in part inherent to life and inevitable (BRAZIL, 2012, p. 41).

The solution to this question given by the 3rd Panel, with the recognition of a duty of care, on the contrary, is compatible with a broader understanding of parental duties, enabling the inclusion of the duty to direct the upbringing and education of children, provided for in art. 1634, I, of the CC (BRAZIL, 2012).

18 In fact, this is an objection that has already been made regarding the reparability of non-pecuniary damages in general (MELO DA SILVA, 1983, p. 360-367).

19 Although adversity is an opportunity for the growth of the individual, it seems to us that overcoming it should be considered the merit of the person who faced it, not a justification for the conduct of the person who caused it. 


\subsection{MATERnAl CO-RESPONSIBILITY}

Finally, we have the argument that the value of reparation should be reduced in proportion to the father's contribution to the neglect of the child. The assumption is that the mother is co-responsible for the neglect practiced by the father, when adopting aggressive conduct towards him. The possibility of the father reacting to his partner's aggression other than by abandonment (for example, by asking for custody of the child) or the aggression of the mother being provoked by the faulty father himself is not considered. ${ }^{\mathbf{2 0}}$

The argument of maternal co-responsibility is especially interesting for our analysis for two reasons. Firstly, because it was defended by Justices Sidnei Beneti and Paulo de Tarso Sanseverino in opinions in favor of reparation for the damages resulting from child neglect, even if only in exceptional cases (BRAZIL, 2012, p. 36-37; 44). This shows that the male bias is even in the constitution of the winning thesis itself in the STJ.

Secondly, because the argument contradicts express statutory rule. Even if one understands that the mother contributed to the practice of unlawful behavior by acting aggressively towards the father, thus preventing or hindering his access to and regular contact with the child, and that she should therefore be considered co-responsible for the harm deriving from paternal abandonment, it would be a case of joint liability, by virtue of art. 942 of the CC.

This means that the victim of the wrongdoing can choose against whom to bring the action of liability in tort and that any of the co-responsible wrongdoers may be compelled to pay the entire amount of damages (CC, art. 275). The person who pays the total damages can later compel the other co-responsible wrongdoer to reimburse their own share of the debt (CC, art. 283).

According to the express statutory text, the father should therefore be ordered to pay the full amount of the reparation, and - if he wished - charge the mother of his child the portion of this payment that corresponds to her participation in the wrongdoing.

Despite this, Justice Sidnei Beneti concludes that "the amount set is excessive, because the proportionality of the action and omission of the father, now Appellant, in causing the moral distress to the daughter, now Appealed, was not taken into account” (BRAZIL, 2012, p. 37, our translation). The rule of joint liability was not even considered in this case.

20 In an opinion in which he reduces the amount of damages based on the mother's co-responsibility, Justice Sidnei Beneti does so "in spite of human sympathy for the situation of the mother, who, according to the file, had a premarital relationship with the defendant, now Appellant, for eight years, who left her pregnant shortly before the birth of the plaintiff daughter, who only had her paternity recognized by court decision after long-term resistance from the father in a long legal process" (BRAZIL, 2012 , p. 37, our translation). It should also be noted that, by reducing the value of the conviction to half the amount granted by the previous instance, Justice Sidnei Beneti considers that the mother contributed to the abandonment to the same extent as the father (BRAZIL, 2012, p. 38). 
Not only is the woman-mother burdened with raising her child without a paternal presence, but also the civil liability for the negative consequences of parental neglect. As the data on poverty in Brazil indicate, being a single mother alone is a considerable social disadvantage. The idea of maternal co-responsibility for neglect reinforces the power asymmetry between the father-men and the mother-women, not only in the dimension of material living conditions, but also in the symbolic dimension. Given that the cultural aspect of gender stratification is one of the most persistent, the question of maternal co-responsibility is a matter of great relevance for the achievement of equality between men and women.

\section{THE EXISTENCE OF AlTERNATIVE ARguments}

The male bias of the above arguments becomes more evident to the extent that reasonable legal arguments can be developed that do not imply the use of gender stereotypes, nor the devaluation of interests or fields of human experience considered feminine, or comparatively greater detrimental effects to women.

In the case of the STJ's rulings on child neglect, such alternative positions were, in fact, defended in both Panels and since the first decision on the subject.

In the 4th Panel in 2005, Justice Barros Monteiro, in his dissenting opinion, stated that the sanction of loss of parental authority does not exclude the parent's liability for non-pecuniary damages (BRAZIL, 2005, p. 13).

In the 3rd Panel, there is the opinion of Justice Nancy Andrighi, who expressly refutes the argument of the uniqueness of Family Law, stating that there are no legal restrictions on the application of liability rules to family relations. On the contrary, according to the justice, the statutory texts dealing with civil liability do so "broadly and unrestrictedly, from which it can be inferred that they regulate even relationships born within a family nucleus in their various forms" (BRAZIL, 2012, p. 5-6).

The justice also expressly responds to the argument that the sanction of loss of parental authority would be sufficient in such cases, stating that the imposition of such a sanction cannot exclude reparation, "because its primary objective is to safeguard the integrity of the minor by offering through other means, the upbringing and education denied by the parents, and never to compensate for the damage that comes from the poor care the child received" (BRAZIL, 2012, p. 6).

Justice Nancy Andrighi - as well as Justice Barros Monteiro before her (BRAZIL, 2005, p. 13) - structures her argument from the general elements of civil liability: unlawfulness, fault, harm, and causation (BRAZIL, 2012, p. 6-14).

The most controversial aspect of liabilitty for child neglect is unlawfulness, that is, the violation of a legal duty. In this regard, Justice Nancy Andrighi points out that the relationship between parents and children is not only emotional, but also legal and that: 
Among the duties inherent to parental authority, stand out the duty of coexistence, care, raising and education of the children, aspects that obviously involve the necessary transmission of attention and the accompaniment of the child's social-psychological development. (BRAZIL, 2012, p. 7, our translation)

So, continues the justice,

the debate acquires more technical contours, since the measurement of the intangible - love - is no longer discussed, but rather the verification of compliance, non-compliance, or partial fulfillment of a legal obligation: care. (BRAZIL, 2012, p. 10, emphasis in original)

The justice responds to the argument that it is impossible to force love by identifying the element of unlawfulness in the breach of the legal duty of care, concluding in this respect that "loving is a faculty, caring is a duty" (BRAZIL, 2012, p. 11, our translation).

\section{CONCLUSION}

The analysis of the debate on civil liability for child neglect in the STJ allows us to conclude that both in the 3rd as well as the 4th Panel and throughout the period in which the debate developed - from the first case to the Embargos de Divergência judgment on the issue - sexist arguments were involved.

Male biases are present in both unfavorable and favorable opinions for reparation. The male biases are shown by the disregard of the doctrinal tradition and the specialized literature, as well as by the disregard of the ambivalent character of family relations and their hierarchical structures. This bias is shown, furthermore, through the express devaluation of female interests and life experiences, via the use of negative female stereotypes, and through problems in argumentative logic and systematic interpretation of the law, and even disregard of an express statutory norm. It is clear that the STJ was not able to take into account the female point of view and the concrete circumstances in which child neglect happens today in Brazil, nor its consequences for women-mothers in single-parent families.

The result is that the STJ developed the concept of indemnifiable harm in a sense that, while apparently gender neutral, is in reality founded on discriminatory rationale and has disproportionately more severe effects on women.

Obviously, we do not mean that liability for child neglect is the solution to the problem of the burden that domestic and care work has on women-mothers in single-parent families. It seems to us that civil liability should not be a central element of a gender equality policy, due to the institution's own limitations.

Tort liability depends on expensive, time-consuming, and uncertain success in court 
proceedings. In addition, for the reparation to actually take place, the father must be able to afford it.

Given the fact that abandonment leads to poverty for most of these families, especially those headed by black women, it is clear that this is an alternative available only to a minority of daughters, sons, and mothers.

The emancipation of women-mothers who raise their children in situations of paternal abandonment depends on advances in other fields, especially public policies to support female work, social security, and the care of children, the elderly, and the sick (ITABORAÍ, 2017, p. 342).

Still, it cannot be admitted that the development of tort liability by courts - or of any other legal institution - follows in the opposite direction from the pursuit of gender equality. The STJ's decisions, based on sexist arguments, reinforce the existing gender hierarchy and undermine the achievement of the constitutional objective of gender equality.

Therefore, our analysis recommends a broader investigation into the male biases embedded in the legal institutions of private law, with the aim of presenting the problem explicitly for democratic reflection.

The gender biases implicit in court rulings also raise the fundamental question of the permeability of courts to female voices; and thus the question of the relationship between legal doctrine and the institutional structure of the courts themselves and of the entire justice system from law schools through the structure of the judicial and administrative procedures to the structure of access, promotion, etc. of judges.

The fact that within the STJ itself there were dissonant opinions, on the other hand, allows us to conclude this article optimistically as to the potential for legal doctrine to play a role in promoting equality, rather than merely reinforcing the hierarchy between the sexes, which is still very present in Brazilian society.

\section{ACKNOWLEDGEMENTS}

The author would like to thank Camila de Jesus Mello Gonçalves and the Paulista School of Magistracy, for the invitation to present a lecture on the feminist analysis of child neglect, which was the origin of this article. Acknowledgments are also due to Catarina Helena Cortada Barbieri and to the anonymous reviewers of GV Law Review for their careful reading and criticism that resulted in the improvement of the work, and Ricardo Savignani Álvares Leite for his assistance in formatting the text. Finally, I would like to acknowledge the importance of Fernando 
Carvalho de Paula Côrtes taking on the role of primary caregiver for our daughter's early years in making my return to academic work possible.

\section{REFERENCES}

BARTLETT, Katharine T. Feminist Legal Methods. Harvard Law Review, v. 103, n. 4, p. 829-888, 1990.

BERALDO DE OLIVEIRA, Marcella. Da Delegacia de Defesa da Mulher ao Juizado Especial Criminal: significados da violência de gênero no fluxo processual. In: DEBERT, Guita Grin et alii. Gênero, família e gerações: Juizado Especial Criminal e Tribunal do Júri. Campinas: Núcleo de Estudos de Gênero Pagu/Unicamp, 2008. p. 15-49.

BRAZIL. Brazilian Superior Court of Justice (STJ). Recurso Especial n. 757411, $4^{\mathrm{a}}$ Turma, Relator: Min. Fernando Gonçalves, j. em 29.11.2005. Available at: https://ww2.stj.jus.br/processo/revista/ documento $/$ mediado $/$ ?componente $=I T A \&$ sequencial $=595269 \&$ num_registro $=200500854643 \&$ data $=$ 20060327\&formato=HTML. Accessed on: 29 Sep. 2017.

BRAZIL. Brazilian Superior Court of Justice (STJ). Recurso Especial n. 514350, $4^{\mathrm{a}}$ Turma, Relator: Min. Aldir Passarinho Junior, j. em 28.04.2009a. Available at: https:/ /ww2.stj.jus.br/processo/revista/ documento $/$ mediado $/$ ?componente $=I T A \&$ sequencial $=877545 \&$ num_registro $=200300209553 \&$ data $=$ 20090525\&formato=HTML. Accessed on: 29 Sep. 2017.

BRAZIL. São Paulo State Court of Justice. Apelação n. 3417874/2-00, $9^{a}$ Câmara de Direito Privado, Relatora: Graciella Salzman, j. em 27.03.2009b. Available at: https: / / esaj.tjsp.jus.br/cjsg/getArquivo.do? conversationId $=\& \mathrm{cdAcordao}=3595761 \& \mathrm{cdForo}=0 \&$ uuidCaptcha $=$ sajcaptcha_c75df96573144810b3cdda a0a02c7c30\&vlCaptcha $=$ pKj\&novoVICaptcha $=$. Accessed on: $1^{\text {st }}$ Nov. 2018.

BRAZIL. Brazilian Superior Court of Justice (STJ). Recurso Especial n. 1159242, $3^{\mathrm{a}}$ Turma, Relatora: Min. Nancy Andrighi, j. em 24.04.2012. Available at: https://ww2.stj.jus.br/processo/revista/documento/ mediado $/$ ?componente $=I T A \&$ sequencial $=1067604 \&$ num_registro $=200901937019 \&$ data $=20120510 \&$ fo rmato=HTML. Accessed on: 29 Sep. 2017.

BRAZIL. Brazilian Superior Court of Justice (STJ). Embargos de Divergência em RESP n. 1159242 , $2^{a}$ Seção, Relator: Min. Marco Buzzi, j. em 09.04.2014. Available at: https://ww2.stj.jus.br/processo/ 
revista $/$ documento $/$ mediado $/$ ?componente=ITA\&sequencial=1313315\&num_registro=201201079216 $\&$ data $=20140523 \&$ formato $=$ HTML. Accessed on: 29 Sep. 2017.

CHAMALLAS, Martha. Introduction to Feminist Legal Theory. 2. ed. New York: Aspen Publishers, 2003.

CHAMALLAS, Martha. Introduction to Feminist Legal Theory. 3. ed. New York: Wolters Kluwer, 2013.

CHAMALlAS, Martha; WRIGGINS, Jennifer B. The Measure of Injury: Race, Gender, and Tort Law. New York: New York University Press, 2010.

CNJ - NATIONAL COUNCIL OF JUSTICE. Pai presente e certidões. 2. ed. 2015. Available at: http: / / www. cnj.jus.br/files/conteudo/destaques/arquivo/2015/04/b550153d316d6948b61dfbf7c07f13ea.pdf. Accessed on: 13 Nov. 2018.

DEBERT, Guita Grin; BERALDO DE OLIVEIRA, Marcella. Os modelos conciliatórios de solução de conflitos e a "violência doméstica”. Cadernos Pagu, v. 29, p. 305-337, 2007.

DIAS, Maria Berenice. Manual de direito das famílias. 8. ed. São Paulo: Revista dos Tribunais, 2011.

DWORKIN, Ronald. Law's Empire. Cambridge: Harvard University Press, 1986.

FEINMAN, Martha Albertson. Our Sacred Institution: The Ideal of the Family in American Law and Society. Utah Law Review, n. 2, p. 387-406, 1993.

HIRONAKA, Giselda Maria Fernandes Novaes. Pressuposto, elementos e limites do dever de indenizar por abandono afetivo. In: PEREIRA, Tânia da Silva; PEREIRA, Rodrigo da Cunha. A ética da convivência familiar e sua efetividade no cotidiano dos tribunais. Rio de Janeiro: Forense, 2006. p. 131-149.

IPEA - INSTITUTE FOR APPLIED ECONOMIC RESEARCH. Retrato das desigualdades de gênero e raça. n.d. Available at: http: / /www.ipea.gov.br/retrato/indicadores_chefia_familia.html. Accessed on: 12 Nov. 2018.

ITABORAÍ, Nathalie Reis. Mudanças nas famílias brasileiras (1976-2012). Uma perspectiva de classe e gênero. Rio de Janeiro: Garamond, 2017.

LOBO, Paulo. Direito Civil. Famílias, v. 5, 8. ed. São Paulo: Saraiva, 2018.

MacKINNON, Catharine. Feminism in Legal Education. Legal Education Review, v. 85, p. 85-95, 1989.

MacCORMICK, Neil. Rhetoric and the Rule of Law. Oxford: Oxford University Press, 2005. 
MADALENO, Rolf. O preço do afeto. In: PEREIRA, Tânia da Silva; PEREIRA, Rodrigo da Cunha. A ética da convivência familiar e sua efetividade no cotidiano dos tribunais. Rio de Janeiro: Forense, 2006. p. 151-169.

MELO DA SILVA, Wilson. O dano moral e sua reparação. 3. ed. Rio de Janeiro: Forense, 1983.

MORAES, Maria Celina Bodin. Danos morais em família? Conjugalidade, parentalidade e responsabilidade civil. In: PEREIRA, Tânia da Silva; PEREIRA, Rodrigo da Cunha. A ética da convivência familiar e sua efetividade no cotidiano dos tribunais. Rio de Janeiro: Forense, 2006. p. 171-201.

PARADELLA, Rodrigo. Diferença cai em sete anos, mas mulheres ainda ganham 20,5\% menos que homens. Agência IBGE Notícias, 2019. Available at: https: / /agenciadenoticias.ibge.gov.br/agencia-noticias/2012age...i-em-sete-anos-mas-mulheres-ainda-ganham-20-5-menos-que-homens. Accessed on: 17 Sep. 2019.

PEREIRA, Rodrigo da Cunha. Responsabilidade civil pelo abandono afetivo. In: MADALENO, Rolf; BARBOSA, Eduardo. Responsabilidade civil no direito de família. São Paulo: Atlas, 2015. p. 399-410.

PÜSCHEL, Flavia Portella. Responsabilidade. In: RODRIGUEZ, José Rodrigo. Fragmentos para um dicionário crítico de direito e desenvolvimento. São Paulo: Saraiva, 2011 . p. 167-182.

PÜSCHEL, Flavia Portella; AQUINO, Theófilo Miguel de. Segurança jurídica e coerência: uma reflexão sobre a uniformização de jurisprudência a partir da responsabilidade por abandono afetivo no STJ. Revista da Faculdade de Direito UFPR, v. 64, n. 2, p. 183-204, 2019.

RENAUX, Pedro. Mulheres continuam a cuidar mais de pessoas e afazeres domésticos que homens. Agência IBGE Notícias, 2018a. Available at: https: / /agenciadenoticias.ibge.gov.br/agencia-noticias/2012-agen...tinuama-cuidar-mais-de-pessoas-e-afazeres-domesticos-que-homens. Accessed on: 17 Sep. 2019.

RENAUX, Pedro. Pobreza aumenta e atinge 54,8 milhões de pessoas em 2017. Agência IBGE Notícias, 2018b. Available at: https: / /agenciadenoticias.ibge.gov.br/agencia-noticias/2012-age.../23299-pobreza-aumentae-atinge-54-8-milhoes-de-pessoas-em-2017. Accessed on: 18 Sep. 2019.

RODRIGUEZ, José Rodrigo. Prefácio. In: RODRIGUEZ, José Rodrigo; PÜSCHEL, Flavia Portella; MACHADO, Marta Rodriguez de Assis. Dogmática é conflito: uma visão crítica da racionalidade jurídica. São Paulo: Saraiva, 2012a. p. 9-15.

RODRIGUEZ, José Rodrigo. Dogmática é conflito: a racionalidade jurídica entre sistema e problema. In: RODRIGUEZ, José Rodrigo; PÜSCHEL, Flavia Portella; MACHADO, Marta Rodriguez de Assis. Dogmática é conflito: uma visão crítica da racionalidade jurídica. São Paulo: Saraiva, 2012b. p. 21-32. 
SCHREIBER, Anderson. Responsabilidade civil e direito de família: a proposta da reparação não pecuniária. In: MADALENO, Rolf; BARBOSA, Eduardo. Responsabilidade civil no direito de família. São Paulo: Atlas, 2015. p. 32-49.

SCHWARTZ, Gary T. Feminist Approaches to Tort Law. Theoretical Inquiries in Law, v. 2, n. 175, p. 177-209, 2001.

UNODC - UNITED NATIONS OFFICE ON DRUGS AND CRIMES. Global Study on Homicide. Vienna: UNODC, 2011. Available at: http: / / www.unodc.org/documents/data-and-analysis/statistics/Homicide / Globa_study_on_homicide_2011_web.pdf. Accessed on: 3 Dec. 2018.

WAISELFISZ, Julio Jacobo. Mapa da violência 2015: homicídio de mulheres no Brasil. Brasília, 2015. Available at: http:/ / www.mapadaviolencia.org.br/pdf2015/MapaViolencia_2015_mulheres.pdf. Accessed on: 19 Nov. 2018.

\section{HOW TO QUOTE THIS ARTICLE:}

PÜSCHEL, Flavia Portella. A feminist analysis of child neglect cases from the Brazilian Superior Court of Justice. Revista Direito GV, v. 16, n. 1, Jan./Apr. 2020, e1944. doi: http://dx.doi.org/ 10.1590/2317-6172201944.
Flavia Portella Püschel

PhD in LaW at University of São Paulo (USP). Associate Professor at the São Paulo law School of the Getulio VARGAS FOUNDATION (FGV DIREITO SP).

Flavia.Puschelafgv.br 